\title{
Managing Gene Expression in Pseudomonas Simiae EGD-AQ6 for Chloroaromatic Compound Degradation
}

\section{Saheli Ghosh}

CSIR-NEERI: National Environmental Engineering Research Institute CSIR

Hemant Purohit

CSIR-NEERI: National Environmental Engineering Research Institute CSIR

Asifa Qureshi ( $\sim$ a_qureshi@neeri.res.in )

CSIR-NEERI: National Environmental Engineering Research Institute CSIR https://orcid.org/0000-00018719-4482

\section{Research Article}

Keywords: biofilm, planktonic, phenotype, chloroaromatic degradation, gene expression

Posted Date: June 14th, 2021

DOI: https://doi.org/10.21203/rs.3.rs-385600/v1

License: (9) This work is licensed under a Creative Commons Attribution 4.0 International License. Read Full License

Version of Record: A version of this preprint was published at Archives of Microbiology on January 9th, 2022. See the published version at https://doi.org/10.1007/s00203-021-02737-1. 


\section{Abstract}

Pseudomonas simiae EGD-AQ6 showed utilization of chloroaromatic compound, 2-4dichlorophenoxyacetic acid (2,4-D) efficiently in its biofilm phenotype. The differential rates of accumulation of intermediate metabolite 4-chlorocatechol (4-CCA) were significant in both planktonic and biofilm phenotypes; also increased number of biofilm cells were observed during 2,4-D utilization. Interestingly, response surface analysis demonstrated the combined positive effects of 2,4-D degradation and 4-CCA accumulations. Also, gene expression profiles showed significant up-regulation of degradative and biofilm genes (particularly pellicle forming genes) in the biofilm phenotypes than their planktonic counterparts, thereby confirming occurrence of phenotype variations of Pseudomonas simiae EGD-AQ6 during chloroaromatic degradation. Furthermore, the sequence similarity of the 2-4-D catabolic genes and biofilm forming proteins ( $p e l A B C D E F G$ and pga $A B C D$ ) which are responsible for building carbohydrate rich extracellular matrix, were significant with the respective organisms as revealed through genome analysis. This is the first report, which endorses this Pseudomonas simiae species to be unique in chloroaromatic degradation through phenotype variation, thereby proving as a potential candidate in the improvement of bioremediation technologies.

\section{Introduction}

Chloro-aromatic compounds are released to the environment through runoffs from solvents, dielectric hydraulic fluids and in the form of pesticides as agrochemicals. It caused significant pollution of soil and groundwater throughout this time (Field et al., 1995). 2-4-dichlorophenoxyacetic acid (2-4-D) belongs to the group of chlorophenoxy herbicides widely used as plant growth regulators, most often for the treatment of tomatoes (Kumar et al. 2016). It is significantly toxic, mutagenic, and carcinogenic effects on animals and humans (Zharikova et al. 2018). Although many chlorophenoxy herbicides are recalcitrant, there are bacteria capable of aerobic degradation (Feld et al. 2016). Nevertheless, 2-4-D is used as a model chloro-aromatic compound to investigate the role, on account of its evolution, acute toxicity, and prolonged pollution history in the contaminated niches (Song 2014). But the degradative ability of the authochthonous or augmented planktonic bacteria often declines due to suboptimal conditions such as temperature, $\mathrm{pH}$, partial pressure of oxygen, toxic substances, resulting to which bacterial activity and viability diminishes and impedes degradation (Ghosh et al. 2019b). However, biofilm mediated remediation is inescapably efficacious and gaining interest worldwide. The spatial structure in a biofilm matrix grants heterogeneous microenvironments, sharing of intermediates, horizontal gene transfers, maintains optimal physical conditions due to mass transfer balance (Palmer et al. 2007; Flemming et al. 2016; Abe et al. 2020). This ensures deterrence against stress to the underlying members in the biofilm, leading to the evolution of altered physiology in a population of the same strain as well as in a community (Ghosh et al. 2017b; Tsang and Simpson 2020). The cells are generally characterized by one or more phenotype(s), each with distinct degradative functionality (Ghosh et al., 2017a). In addition, variety of phenotypes with distinct characteristics can often be observed depending on the presence of multiple gradients i.e., nutrient and oxygen within the biofilm microenvironment (Caro- 
Astorga et al. 2020). This implicated to efficient utilization and degradation of the toxic aromatic substrates without inhibiting the underlying cells (Flemming et al. 2016; Ghosh et al. 2017a). In view of above reports, this study is the first to report the influence of such phenotypic variation towards 2-4-D degradation and conditional accumulation of intermediate i.e., 4-chlorocatechol (4-CCA). Also, combined positive effects of the 2-4-D and 4-CCA utilization rates on differential expression of biofilm matrix and degradative genes were observed with escalated up-regulation in the biofilm adapted phenotypes comparative to its planktonic counterpart through response surface analysis. Furthermore, sequence similarity of the biofilm and 2-4-D catabolic genes in P. simiae EGD-AQ6 were found significant with the respective bacteria, thereby advocating $P$. simiae to be an efficient candidate in the development of bioaugmentation technologies.

\section{Materials And Methods}

\subsection{Media, strains and chemicals}

The neutral minimal media (NMM) $(\mathrm{ml} / 1000 \mathrm{ml})$ was used throughout the study whose composition are, $10 \% \mathrm{MgSO}_{4}(2 \mathrm{ml}), 10 \% \mathrm{NH}_{4} \mathrm{Cl}(2.5 \mathrm{ml}), 10 \% \mathrm{CaCl}_{2}(1 \mathrm{ml})$, Na-K Phosphate buffer $(50 \mathrm{mM} ; \mathrm{pH}=7.0), 20 \mathrm{ml}$ $1 X$ Hunter's mineral solution $\left[10 \mathrm{~g} \mathrm{I}^{-1} \mathrm{C}_{6} \mathrm{H}_{9} \mathrm{NO}_{6}, 14.45 \mathrm{~g} \mathrm{I}^{-1} \mathrm{MgSO}_{4}, 3.33 \mathrm{~g} \mathrm{I}^{-1} \mathrm{CaCl}_{2}, 9.25 \mathrm{mg} \mathrm{I}^{-1}\right.$ $\left(\mathrm{NH}_{4}\right)_{2} \mathrm{MoO}_{4}, 99 \mathrm{mg} \mathrm{l}^{-1} \mathrm{FeSO}_{4}, 50 \mathrm{ml} \mathrm{I}^{-1}$ metal 44 solution (25mg/L EDTA, 0.1 mg/L ZnSOه, 50mg/L $\left.\left.\mathrm{FeSO}_{4}, 15.4 \mathrm{mg} / \mathrm{L} \mathrm{MnSO} \otimes 3.92 \mathrm{mg} / \mathrm{L}, \mathrm{CuSO}_{4}, 2.48 \mathrm{mg} / \mathrm{L}, \mathrm{Co}\left(\mathrm{NO}_{3}\right)_{2}, 1.77 \mathrm{mg} / \mathrm{L}, \mathrm{Na} \otimes[\mathrm{B} \otimes \mathrm{O} \otimes(\mathrm{OH}) \otimes] \cdot 8 \mathrm{H} \otimes \mathrm{O}\right)\right] .2-4-$ $\mathrm{D}$ was used as a carbon source. All the chemicals used were of analytical grade. The isolate was subjected to biochemical tests and was regarded as Pseudomonas $s p$ then the whole genome sequences were submitted to NCBI and finally identified as Pseudomonas simiae EGD-AQ6 (16S Genbank accession no: 0204_28505). The isolate has been deposited in Microbial Culture Collection (NCCS Pune, India) with accession MCC 0030 under IDA.

\subsection{Biofilm formation analysis by Pseudomonas simiae EGD-AQ6 in media amended with 2-4-D}

To analyze biofilm formation by Pseudomonas simiae EGD-AQ6, $0.010 . \mathrm{D}_{600} / \mathrm{ml}$ cells were inoculated in NMM medium supplemented with 2-4-D (44.2 to $442 \mathrm{mg} / \mathrm{L}$ ) for shaken and static flask assays (Verhagen et al. 2011; Ghosh et al. 2017a). Crystal violet binding assay in $6 \mathrm{ml}$ microplates were performed as described in Ghosh et al. (2017a) after every 24 hrs of interval upto 288 hrs under static and shaking conditions. For the enumeration of attached cells, standard curve with positive correlation between crystal violet retention O.D and CFU count was determined $\left(r^{2}=0.965\right.$ at $\left.p<0.05\right)$ as per the method described in Ghosh et al. (2019a). The rate of biofilm formation were also determined according to Ghosh et al. (2019a). The suspended cultures from the microplates i.e., unattached cells (planktonic) growth rate was determined as per Wood et al. (2019).

$\mu=\left(\ln 0 . D_{t}-\ln 0 . D_{t 0}\right) /\left(t-t_{0}\right) \ldots \ldots \ldots \ldots \ldots . . . . E q .1$. 
$\mu=$ growth rate, $O . D_{t}$ and $O . D_{t 0}$ are the respective optical densities taken at times $t$ and $t_{0}$.

\subsection{Analytical methods}

To analyze 2-4-D utilization and intermediate metabolite formation high performance liquid chromatography (HPLC) was performed. The supernatants from static and shaking cultures were obtained after every $24 \mathrm{hrs}$ interval, which were filtered through a $0.22 \mu \mathrm{m}$ nylon filters (Randisc, Inc). Filtrates $(20 \mu \mathrm{l})$ were injected through a Lichrosorb RP18, $5 \mathrm{~mm}(250$ X $4.6 \mathrm{~mm})$ column. Metabolites were detected in $284 \mathrm{~nm}$ with an isocratic flow rate of $0.6 \mathrm{ml} / \mathrm{min}$ in Waters PDA detector (Waters, PDA LC) with LC pump 5000 using mobile phase ( $80 \%$ Acetonitrile $+19 \%$ Acetic acid $+1 \%$ water). The 2-4-D degradation and 4-CCA accumulation rates were determined according to the Oberoi et al. (2015).

\subsection{Gene expression analysis: qRT-PCR}

The expression of respective genes i.e., biofilm ( $p e l A, p g a A)$ and catabolic genes ( $a r h d, t f d C$ ) (Franklin et al. 2011; Camara et al. 2009) were obtained under static and shaking conditions. Real-time primers were designed (Table. S1) using DNA star (Lasergene, USA) and checked for their specificity by PCR amplification (data not shown). Total RNA extraction, qRT-PCR and relative quantification of EGD-AQ6 cells were performed as described by Ghosh et al. (2017a) using the $2^{\Delta \Delta \mathrm{Ct}}$ method using rpoB as a housekeeping gene (Livak et al. 2013).

\subsubsection{Design of experiments: Response surface methods (RSM)}

RSM approach was used to test the effect of 2-4-D degradation and 4-CCA accumulation on the expression of biofilm and catabolic genes ( $p g a A$ and pelA; arhd and $t f d C$ ) under static and shaking conditions. Here, 2-4-D degradation rate (factor A), 4-CCA accumulation rate (factor $B$ ) were regarded as two input variables to study their effect on four response functions $p g a A$, pelA, arhd, $t f d C$ expression rates separately under static and shaking phases. The optimal ranges of two factors used were based on preliminary experiments (Fig. 1) to determine the range of values of parameters for effective responses. RSM with central composite design (CCD) was used as a factorial experimental design in this study. Design of experiments, mathematical modeling, and optimization was performed by Minitab v19 (trial version) software. Here, the minimal media were amended with the amounts of 2-4-D and 4-CCA for the four responses, i.e., on the above-mentioned gene expression rates up to $144 \mathrm{hrs}$ according to the combinations suggested by the software. Calculations and CCD analyses were then performed. For two variables $(n=2)$ and five levels [low $(-1)$, high $(1), 0,+a,-a]$, the total number of the experimental run was 13 as determined by the software with 4 factorial points, 4 axial points and 6 center points (six replications) as given in Table 1. The fitted regression model was checked using regression analysis and ANOVA. The significance and robustness of the model were determined using ( $R^{2}$-Value), F-values, and $p$ values. The response variables were considered to be significant when $p<0.05$. In general, the response for the quadratic polynomials is described below: 
where $Y=$ response, $X_{j}$ and $X_{j}$ are the variables, $\beta_{0}$ is the constant coefficient, $\beta i i, \beta i$, and $\beta i j$ are the coefficients of the quadratic, linear, and interaction effect, and $k$ is the no of factor variables.

$$
\mathrm{Y}=\beta_{0}+\sum_{i=1}^{k} \beta_{i} X_{i}+\sum_{i=1}^{k} \beta_{i i} X_{i}^{2}+\sum_{i}^{k} \sum_{j} \beta_{i} X_{i} X_{j} \ldots \ldots \ldots . . \mathrm{Eq} .2
$$

\subsection{Pseudomonas simiae EGD-AQ6: Whole genome analysis}

Whole genome sequences of Pseudomonas simiae EGD-AQ6, were assembled as per Ghosh et al., 2017 and submitted to NCBI under accession no: AVQG00000000. NCBI has previously characterized the strain to be $P$. fluorescens EGD-AQ6. However, the taxonomic statistics of the strain was updated based on the ANI index which $99.4 \%$ identical to $P$. simiae than $88.4 \%$ with P.fluorescens. Hence, NCBI has renamed the strain as Pseudomonas simiae EGD-AQ6. Here in this report, the genome sequences were selectively analyzed for sequence similarity of biofilm and 2-4-D catabolic genes with the reported organisms.

\section{Results And Discussion}

\subsection{2-4-D degradation and biofilm formation analysis of $P$. simiae EGD-AQ6 under static and shaking phases.}

The influence of specific growth conditions renders bacteria transfigure into variable phenotypes (Mangwani et al. 2015). These are adaptation strategies used to defend against the stress imposed (Jefferson et al. 2004). Reports point out that static and shaking conditions allow bacteria to evolve into different phenotypes such as biofilm (attached) and planktonic (unattached) cells, which influence aromatic degradation efficiency and other biotechnological reactions (Verhagen et al. 2011; Mangwani et al. 2015; Ghosh et al. 2019a). This was observed in our study; as shown in Fig. 1a, the rates of 2-4-D degradation were similar in both static and shaking conditions. On the contrary, 4-chlorocatechol (4-CCA) accumulation were significantly different under both the phases, where the culture supernatants of cells adapted under shaking conditions showed significant 4-CCA accumulation $\left(0.014-0.096 \mathrm{mg}^{-\mathrm{L}} / \mathrm{hr}\right)$ than the cells evolved in static conditions $\left(0.0011-0.0026 \mathrm{mg}^{-\mathrm{L}} / \mathrm{hr}\right)$ at all 2-4-D concentrations (Fig. $\left.1 \mathrm{~b}\right)$. The cell adherence rates were found to be elevated (Fig. 2a) Alternatively, the planktonic cell growth rates were found to be signifcantly lower, thereby suggesting a phenotype switch in the biofilm associated cells (Fig. 2b). A similar degradation trend was observed during the phenol and benzoate biodegradation by Pseudomonas sp. The intermediate catechol accumulated significantly higher in the planktonic cells than the biofilm adapted phenotype of the same strain (Yong and Zhong 2013). Another report where catechol accumulation was minimum in the culture supernatants of biofilm-associated cells during benzoate biodegradation at elevated concentrations (40mM) (Ghosh et al. 2017a), which comply with the present study. 


\subsection{Quantitative expression of biofilm and catabolic genes: Response surface analysis}

The aromatic stress in the chemical surroundings influences phenotype transitions through differential gene expression (Jefferson et al. 2004; Flemming et al. 2016). To test this possibility in our strain, RSM was used to check the combined effects of factors, 2-4-D degradation (A), and 4-CCA accumulation (B) rates on expression rates of biofilm matrix ( $p e l A, p g a A$ ) and catabolic genes ( $a r h d, t f d C$ ) (responses) separately under static and shaking conditions. Real-time PCR analysis showed differential expression levels of the biofilm matrix and catabolic genes in biofilm and planktonic adapted phenotypes, as shown in the contour plots (Fig. 3), which were similar to the predicted values calculated by the Minitab software (Table: S2). The calculated $\mathrm{R}^{2}>0.90$ in all the genes indicated that the predictions of the response function were in accordance with the experimental ones at the confidence level of higher than $90 \%$ (ANOVA Table.2). The absolute coefficients of $A$ and $B$ were significantly higher in pelA, pgaA, arhd, and $t f d C$ expression in biofilm adapted phenotype than its planktonic counterpart (Eg.3a-3h). The p-value for interaction terms is $<0.05$ stipulating their significant effect on the regression model. The contour plots illustrating the interaction effect between independent variables on the responses, where the favorable regions for catabolic and biofilm matrix genes were significantly more in the biofilm phenotype than the planktonic counterpart (Fig. 3). It can be observed that expression rates of biofilm matrix genes ( $p e l A$ and $p g a A)$ had a maximum value of $0.075,0.055$ fold change/hr at the high levels $(+1)$ of $A_{1}(1.46)$ and $B_{1}$ (0.00461), respectively (Table: S2). Likewise, the favorable regions for catabolic genes were comparatively different in both the phenotypes, with $t f d C$ showing a noteworthy response in the biofilm phenotype with expression rate 0.023 fold change/hr. It appears that, as the 4-chlorocatechol accumulates rate is lowered, $t f d C$ expression rate increases indicating its utlization in the biofilm adapted cells (Table S1; S2). For every 0.008 fold change/hr of arhd expression, $t f d C$ expression rate was increased by 2.8 times, as that of pelA and pgaA by 9.3 and 6.8 times (Table: S2). On the contrary, this trend is reversed in planktonic associated cells. At high levels $(+1)$ of $A_{2}(1.36)$ and $B_{2}(0.132)$, the expression rates for arhd, $t f d C$, pelA and $p g a A$ were $0.027,0.0102,0.000369,0.0208$. It indicates the decline in $t f d C$ expression rate by 0.2 fold change/hr. The declination of matrix genes expression rates were significant by 73 and 1.29 times comparative to arhd expression. Similarly at low levels $(-1)$ of $A_{2}$ and $B_{2}$, the catabolic and biofilm matrix genes expression rates were significantly dissimilar in both the phenotypes of EGD-AQ6. It also corroborates to the greater participation and importance of the matrix protein pellicle than $p g a A$ in building the biofilm at increasing chloroaromatic compound stress. It is similar to the results obtained by Meliani and Bensoltane (2014), indicates that pellicle synthesis was increased during xylene degradation and conferred an increased biofilm mass to $P$. fluorescens and $P$. aeruginosa. It indicates the combined impact of toxic metabolites, leading to phenotype switch of the strain EGD-AQ6 to combat the stress imposed, resulting in elevated biodegradation potential (Fig. 2a, 2b, $2 e, 2 f)$. In this way, we have managed to unravel the gene expression patterns, regulating the 2-4-D biodegradation in both the phenotypes. Similarly, Yong and Zhong. (2013) reported that a different central cleavage pathway was initiated on account of a phenotype switch during phenol degradation. 
Diverse catabolic, matrix synthesizing pathways and signal transduction mechanisms are involved in the phenotypic switch that allows a bacterium to attain physiological and metabolic heterogeneity.

Furthermore, these pathways are also appear to be interconnected. Therefore, it is very likely that depending on the prevailing conditions, number of variants may appear simultaneously in the same strain (Allison et al. 2011; Amato et al. 2013). Also, this invulnerability of the underlying cells in the biofilm is due to diffusion limitations imparted by local variations in $\mathrm{pH}$, nutrient and oxygen availability, and concentrations of bacterial metabolites leading to physiological heterogeneity, slow growth (Sauer et al. 2002: Jefferson et al. 2004; Flemming et al. 2016). It further influences the activity of dioxygenases through regulating the partial pressure of oxygen in the fluid surroundings (Ding et al. 2008), resulting in differential gene regulation leading to phenotype transition (Paliwal et al. 2014). The interactive effect of the factors on the two responses (Table: S2; Table 2) was statistically quantified, and the approximate functions for attached cells (Eq. 3a, 3c) and planktonic cells (Eq. 3b, Eq. 3d) under static and shaking conditions was obtained as follows.

Under static conditions

$Y_{\text {arhd }}=0.004912+0.000049 A+0.003207 B-0.000430 A * A+0.000185 B * B-0.000254 A * B \ldots \ldots$. Eq. 3a.

$Y_{t f d C}=0.01303+0.00021 A+0.00485 B+0.00181 A^{\star} A-0.00392 B^{\star} B-0.00058 A^{*} B \ldots \ldots .$. Eq. 3b.

$Y_{\text {pelA }}=0.04255+0.00638 A+0.02480 B+0.00184 A^{\star} A+0.00181 B * B-0.01256 A * B \ldots \ldots$. Eq. 3c.

$Y_{p g a A}=0.032250-0.000327 A+0.021895 B-0.001448 A^{\star} A-0.001363 B * B-0.002148 A^{*} B \ldots \ldots$. Eq. 3d.

Under shaking conditions

$Y_{\text {arhd }}=0.001389-0.000059 A+0.000840 B-0.000064 A^{\star} A-0.000024 B^{\star} B-0.000043 A^{\star} B \ldots \ldots$. Eq. 3e.

$Y_{t f d C}=0.030408+0.001127 A+0.002967 B-0.026625 A^{\star} A-0.026187 B^{*} B-0.003062 A^{\star} B \ldots \ldots$. Eq. 3f.

$Y_{\text {pelA }}=0.000022+0.000001 A+0.000015 B-0.000001 A^{\star} A-0.000013 B^{*} B+0.000011 A^{\star} B \ldots \ldots$. Eq. $3 g$

$Y_{p g a A}=0.001389-0.000059 A+0.000840 B-0.000064 A^{*} A-0.000024 B * B-0.000043 A^{*} B \ldots \ldots$. Eq. 3h

Taken together, the gradient-based physical and chemical microenvironments imparted by the matrix to the inhabitants (Palmer et al., 2007; Ghosh et al., 2017b) may have regulated the catabolic activity through oxygen fluctuations and additional alterations in gene expression in the biofilm.

\subsection{Whole-genome sequence (WGS) analysis}

Pseudomonas simiae EGD-AQ6 genome sequence unraveled variable catabolic capacities (NCBI under accession no: AVQG00000000). However, in this study, the 2-4-D degrading gene clusters were characterized, scattered in the two contigs. The gene clusters (tfd genes) showed up to $99 \%$ functional 
homology with the reported degraders (Table: 3) viz; P.simiae WCS417, P.simiae PICF7, P.simiae K-hf-19, P.simiae PCL175.

Another gene cluster showed aromatic ring hydroxylating dioxygenase (arhd) of $P$. simiae EGD-AQ6 62\% sequence homology with $t f d A$ of $R$. eutropha JMP134 as determined using pBLAST and CDD (Table;S5), which is responsible for a-ketoglutarate-dependent dioxygenation, hence regarded as the first enzyme of the pathway. 2-4-D degradation occurs via; the formation of 4-CCA as the central metabolic intermediate (Balajee and Mahadevan, 1993; Zharikova et al., 2018). The degradation proceeds via; further oxidations and hydroxylations through $t f d C D E F$ genes to TCA cycle intermediates similar in $R$. eutropha and Azotobacter chroococcum. (Balajee and Mahadevan, 1993; Camara et al., 2009). Apart from chloroaromatic degrading genes, the region in NCBI (0204_02005-0203_02035) and (0204_26495-0204_26465) encompasses gene clusters in a single operon, which exhibited significant similarity (80-99\%) with the reported biofilm-forming Pseudomonas species (Table S3; S4). They are principal components of biofilm, involved in the building of carbohydrate-rich extracellular matrices such as poly-glucosamine ( $p g a)$ and pellicles (pel) (Itoh et al., 2008; Franklin et al., 2011).

\section{Conclusion}

Pseudomonas simiae EGD-AQ6 showed phenotype (biofilm and planktonic) variation during utilization of toxic chloro-aromatic compound (2-4-D). Biofilm phenotype of Pseudomonas simiae showed comparatively less accumulation of intermediate 4-CCA than its planktonic counterpart. Gene expression profiles exhibited greater up regulation of biofilm matrix genes, particularly pelA in biofilm adapted cells during 2,4-D degradation and verified using RSM. Pseudomonas simiae EGD-AQ6 catabolic genes cluster sequence similarity analysis (up to $99 \%$ ) with other strains of Pseudomonas simiae, further validated our physiological and RSM data. This report states, the occurrence of efficient chloro-aromatic degradation through phenotype variations, thereby envisaging the Pseudomonas simiae EGD-AQ6 to be an effective candidate in designing bioremediation technology.

\section{Declarations}

\section{Ethics approval and consent to participate}

Not applicable

\section{Consent for publication}

Not applicable

\section{Availability of data and materials}

Genome sequencing data is available in NCBI

\section{Conflict of Interest}


The authors have no conflict of interest to declare.

\section{Author contributions}

S.G.: Experimentation, Data Curation, Statistical analysis, Paper writing. A.Q.: inputs, Supervision, Editing, Investigation. H.J.P: inputs and support.

\section{Acknowledgement}

The authors are thankful to Director, CSIR-NEERI for constant support and providing infrastructural facilities (KRC no CSIR-NEERI/KRC/2020/OCT/EBGD/4). The authors are also grateful to Council of Scientific and Industrial Research (CSIR), New Delhi (SG fellowship) and Department of Science and Technology (DST/TM/WTI/2015/225(G)-B/2) for funding.

\section{References}

1. Abe K, Nomura N, and Suzuki S (2020) Biofilms: hot spots of horizontal gene transfer (HGT) in aquatic environments, with a focus on a new HGT mechanism. FEMS Microbiol Ecol 9:

5. https://doi.org/10.1093/femsec/fiaa031

2. Allison KR, Brynildsen MP, Collins JJ (2011) Heterogeneous bacterial persisters and engineering approaches to eliminate them. Curr Opin Microbiol 14:593598. http://dx.doi.org/10.1016/j.mib.2011.09.002.

3. Amato SM, Orman MA, Brynildsen MP (2013) Metabolic control of persister formation in Escherichia coli. Mol Cell 50:475-487. http://dx .doi.org/10.1016/j.molcel.2013.04.002

4. Balajee S, Mahadevan A 1990 Dissimilation of 2,4-dichlorophenoxyacetic acid by Azotobacter chroococcum. Xenobiotica 20: 607-617. https://doi.org/10.3109/00498259009046876

5. Camara B, Nikodem P, Bielecki P, Bobadilla R., Junca H, Pieper D.H (2009). Characterization of a gene cluster involved in 4-chlorocatechol degradation by Pseudomonas reinekei MT1. J Bacteriol 191: 4905-4915. doi: 10.1128/JB.00331-09

6. Caro-Astorga J, Frenzel E, Perkins JR, Álvarez-Mena A, de Vicente A, Ranea JAG, Romero D (2020) Biofilm formation displays intrinsic offensive and defensive features of Bacillus cereus. Npj Biofilms and Microbiomes. 6: 1. DOI: 10.1038/s41522-019-0112-7.

7. Ding B, Schmeling S, Fuchs G (2008) Anaerobic metabolism of catechol by the denitrifying bacterium Thauera aromatica-A result of promiscuous enzymes and regulators?. J Bacteriol 190: 1620-1630. DOI: 10.1128/JB.01221-07

8. Feld L, Nielsen TK, Hansen LH, Aamand J, Albers CN (2016) Establishment of bacterial herbicide degraders in a rapid sand filter for bioremediation of phenoxypropionate-polluted groundwater. Appl Environ Microbiol 82: 878-887. DOI: 10.1128/AEM.02600-15.

9. Field JA, Stams AJM, Kato M, Schraa G (1995) Enhanced biodegradation of aromatic pollutants in cocultures of anaerobic and aerobic bacterial consortia. Anton van Leeuwenhoek. 67:47- 
77. DOI: $10.1007 / B F 00872195$.

10. Flemming HC, Wingender J, Szewzyk U, Steinberg P, Rice SA, Kjelleberg S (2016) Biofilms: an emergent form of bacterial life. Nat Rev Microbiol 14: 563-

575. https://doi.org/10.1038/nrmicro.2016.94.

11. Franklin MJ, Nivens DE, Weadge JY, Howell PL (2011) Biosynthesis of the Pseudomonas aeruginosa extracellular polysaccharides, alginate, Pel \& Psl. Front Microbiol 2: 1-16.

doi: $10.3389 /$ fmicb.2011.00167.

12. Itoh Y, Rice JD, Goller C, et al. (2008) Roles of pgaABCD genes in synthesis, modification, and export of the Escherichia coli biofilm adhesin poly-beta-1,6-N-acetyl-D-glucosamine. J Bacteriol 190: 36703680. DOI: 10.1128/JB.01920-07.

13. Ghosh S, Qureshi A, Purohit HJ (2017a) Enhanced expression of catechol 1, 2 dioxygenase gene in biofilm forming Pseudomonas mendocina EGD-AQ5 under increasing benzoate stress. Int Biodeterior Biodegradation 118: 57-65.

DOI:10.1016/j.ibiod.2017.01.019.

14. Ghosh S, Qureshi A, Purohit HJ (2017b) Biofilm Microenvironments: Modeling Approach. In: Purohit H, Kalia V, Vaidya A, Khardenavis A. (Eds) Optimization and Applicability of Bioprocesses. Springer, Singapore, pp. 305-322. https://doi.org/10.1007/978-981-10-6863-8_15.

15. Ghosh S, Qureshi A, Purohit HJ (2019a) D-Tryptophan governs biofilm formation rates and bacterial interaction in P. mendocina and S. aureus. J Biosci 44: 3. DOI: 10.1007/s12038-018-9841-7

16. Ghosh S, Qureshi A, Purohit HJ (2019b) Aromatic Compounds and Biofilms: Regulation and Interlinking of Metabolic Pathways in Bacteria. In: Arora P. (eds) Microbial Metabolism of Xenobiotic Compounds. Microorganisms for Sustainability, 10: 145-164. Springer,

Singapore. https://doi.org/10.1007/978-981-13-7462-3_7

17. Jefferson KK (2004) What drives bacteria to produce a biofilm? FEMS Microbiol. Lett. 236: 163-173. https://doi.org/10.1111/j.1574-6968.2004.tb09643.x

18. Kumar A, Trefault N, Olaniran AO (2016) Microbial degradation of 2, 4-dichlorophenoxyacetic acid: insight into the enzymes and catabolic genes involved, their regulation and biotechnological implications. Critical Rev Microbiol 42: 194-208. DOI: 10.3109/1040841X.2014.917068

19. Livak KJ, Wills QF, Tipping AJ, Datta K, Mittal R, Goldson AJ, Sexton DW, Holmes CC (2013) Methods for qPCR gene expression profiling applied to 1440 lymphoblastoid single cells. Methods 59: 7179. https://doi.org/10.1016/j.ymeth.2012.10.004

20. Mangwani N, Kumari S, Das S (2015) Involvement of quorum sensing genes in biofilm development and degradation of polycyclic aromatic hydrocarbons by a marine Pseudomonas aeruginosa N6P6. Appl Microbiol Biotechnol 99: 10283-10297. https://doi.org/10.1007/s00253-015-6868-7

21. Meliani A, Bensoltane A (2014) Enhancement of Hydrocarbons Degradation by Use of Pseudomonas Biosurfactants and Biofilms. J Pet Environ Biotechnol 5:1. DOI: 10.4172/2157-7463.1000168.

22. Oberoi AS, Philip L, Bhallamudi SM (2015) Biodegradation of various aromatic compounds by enriched bacterial cultures: part a-monocyclic and polycyclic aromatic hydrocarbons. Appl Biochem 
Biotechnol 176: 1870-1888. https://doi.org/10.1007/s12010-015-1684-1

23. Paliwal V, Raju SC, Modak A, Phale PS, Purohit HJ (2014) Pseudomonas putida CSV86: a candidate genome for genetic bioaugmentation. PLoS One 9:

e84000 https://doi.org/10.1371/journal.pone.0084000

24. Palmer J, Flint S, Brooks J (2007) Bacterial cell attachment, the beginning of a biofilm. J Ind Microbiol Biotech 34: 577-588. DOI: 10.1007/s10295-007-0234-4

25. Sauer K, Camper AK, Ehrlich GD, Costerton JW, Davies DG (2002) Pseudomonas aeruginosa displays multiple phenotypes during development as a biofilm. J Bacteriol 184: 1140-1154. DOI: 10.1128/jb.184.4.1140-1154.2002

26. Song $Y$ (2014) Insight into the mode of action of 2, 4-dichlorophenoxyacetic acid (2, 4-D) as an herbicide. J Int Plant Biol 56: 106-113. DOI: 10.1111/jipb.12131

27. Tsang STJ, Simpson AHRW (2020) Pathogenesis of Biomaterial-Associated Infection. In: Li B., Moriarty T., Webster T., Xing M. (eds) Racing for the Surface. Springer, Cham. https://doi.org/10.1007/978-3-030-34475-7_6.

28. Verhagen P, De Gelder, Hoefman S, De Vos P, Boon N (2011) Planktonic versus biofilm catabolic communities: importance of the biofilm for species selection and pesticide degradation. Appl Environ Microbiol 77: 4728-4735. DOI: 10.1128/AEM.05188-11

29. Wood JS, Osman A, Wade SA (2019) An efficient, cost-effective method for determining the growth rate of sulfate-reducing bacteria using spectrophotometry. MethodsX 6: 2248-2257. doi: 10.1016/j.mex.2019.09.036

30. Yong YC, Zhong JJ (2013) Regulation of aromatics biodegradation by rhl quorum sensing system through induction of catechol meta-cleavage pathway. Bioresour Technol 136: 761765. DOI: 10.1016/j.biortech.2013.03.134

31. Zharikova NV, lasakov TR, Zhurenko El, Korobov VV, Markusheva TV (2018) Bacterial Genes of NonHeme Iron Oxygenases, Which Have a Rieske-Type Cluster, Catalyzing Initial Stages of Degradation of Chlorophenoxyacetic Acids. Russ J Genetics 54: 284-295. https://doi.org/10.1021/cs400087p.

\section{Tables}

Table 1 Coded and uncoded levels of variables of 2-4-D degradation and 4-CCA accumulation. 


\begin{tabular}{|c|c|c|c|c|c|c|}
\hline \multirow[t]{2}{*}{ Conditions } & \multirow[t]{2}{*}{ Variables } & \multicolumn{5}{|c|}{ Coded levels } \\
\hline & & $(-\alpha)-1.414$ & -1 & 0 & 1 & $(+\alpha) 1.414$ \\
\hline \multirow[t]{2}{*}{ Static } & $\begin{array}{l}2-4-\mathrm{D} \\
\text { degradation } \\
\text { rate }\left(\mathbf{A}_{1}\right)\end{array}$ & 0.274275 & 0.135 & 0.7975 & 1.46 & 1.599275 \\
\hline & $\begin{array}{l}4 \text {-CCA } \\
\text { accumulation } \\
\text { rate }\left(B_{1}\right)\end{array}$ & 0.000858636 & 0.0004612 & 0.0025356 & 0.00461 & 0.005007 \\
\hline \multirow[t]{2}{*}{ Shaking } & $\begin{array}{l}2-4-\mathrm{D} \\
\text { degradation } \\
\text { rate }\left(\mathbf{A}_{2}\right)\end{array}$ & 0.253575 & 0.135 & 0.7475 & 1.36 & 1.478575 \\
\hline & $\begin{array}{l}4 \text {-CCA } \\
\text { accumulation } \\
\text { rate }\left(B_{2}\right)\end{array}$ & 0.024633 & 0.013 & 0.0725 & 0.132 & 0.143633 \\
\hline
\end{tabular}

Table: 2 Analysis of variance (ANOVA) for the fitted quadratic polynomial model for attached and unattached (planktonic cells) under static and shaking conditions 


\section{Sum of}

squares
Mean

square
F-

value p value df

prob $>$ F

Static

arhd

$\mathrm{R}^{2}=96.8 \quad$ Mode

$\begin{array}{lllllll}\operatorname{Adj} R^{2}= & A_{1} & 0.000062 & 0.000062 & 12.04 & 0.001 & 1\end{array}$

94.65

$\begin{array}{lllllll}\text { Pred } & \mathrm{B}_{1} & 0.000012 & 0.000012 & 163.42 & 0.001 & 1\end{array}$ $\mathrm{R}^{2}=77.4$

tfdC $\quad \mathrm{R}^{2}=94.2$

$\begin{array}{cccccc}\mathrm{A}_{1}{ }^{2} & 0.000064 & 0.000064 & 2.55 & 0.018 & 1 \\ \mathrm{~B}_{1}{ }^{2} & 0.000014 & 0.000014 & 4.47 & 0.015 & 1 \\ \mathrm{~A}_{1}{ }^{*} \mathrm{~B}_{1} & 0.000011 & 0.000011 & 5.51 & 0.002 & 1 \\ \begin{array}{c}\text { Lack- } \\ \text { of-fit }\end{array} & 0.000004 & 0.000001 & 200.1 & 0.004 & 3 \\ \text { Pure } & 0.000000 & 0.000000 & - & - & 4\end{array}$
error

$\operatorname{Adj} R^{2}=$ Model
(3b)

93.5

Pred $\mathrm{R}^{2}=$

$\mathrm{A}_{1}$

$0.0092 \quad 0.00184$

43.1

$0.001 \quad 5$

78.6

$$
\mathrm{B}
$$

$0.000247 \quad 0.000247$

5.76

$0.048 \quad 1$

$\mathrm{B}_{1}$

0.000266

0.000266

15.49

$0.006 \quad 1$

$\begin{array}{llllll}\mathrm{A}_{1}^{2} & 0.000784 & 0.000784 & 87.41 & 0.0023 & 1\end{array}$

$\begin{array}{llllll}\mathrm{B}_{1}^{2} & 0.003982 & 0.003982 & 72.68 & 0.003 & 1\end{array}$

$\begin{array}{llllll}\mathrm{A}_{1} * \mathrm{~B}_{1} & 0.004497 & 0.004497 & 18.25 & 0.004 & 1\end{array}$

$\begin{array}{llllll}\text { Lack- } & 0.000298 & 0.000099 & 13.98 & 0.003 & 3\end{array}$

of-fit

$\begin{array}{llllll}\text { Pure } & 0.000003 & 0.000001 & - & & -\end{array}$

$\begin{array}{llllllll}\text { pelA } & \mathrm{R}^{2}=96.2 & \text { Model } & 0.005919 & 0.001184 & 13.16 & 0.002 & 5\end{array}$ (3c)

$\begin{array}{lllllll}\operatorname{Adj} \mathrm{R}^{2}= & \mathrm{A}_{1} & 0.000326 & 0.000326 & 3.62 & 0.009 & 1\end{array}$ 90.5

Pred $\mathrm{R}^{2}=$ 88.2 
$\mathrm{R}^{2}=$

99.38

Adj $R^{2}=$ 98.5

Pred $R^{2}=$ 95.70

Shaking

arhd

$(3 d)$

$\begin{array}{llllll}\mathrm{A}_{1} & 0.001918 & 0.001918 & 55.25 & 0.0233 & 1\end{array}$

$\begin{array}{llllll}\mathrm{B}_{1} & 0.002825 & 0.002825 & 113.52 & 0.006 & 1\end{array}$

$\begin{array}{llllll}\mathrm{A}_{1}{ }^{2} & 0.000015 & 0.000015 & 4.24 & 0.019 & 1\end{array}$

$\begin{array}{llllll}\mathrm{B}_{1}{ }^{2} & 0.000013 & 0.000013 & 3.75 & 0.014 & 1\end{array}$

$\begin{array}{llllll}\mathrm{A}_{1} * \mathrm{~B}_{1} & 0.000018 & 0.000018 & 5.36 & 0.014 & 1\end{array}$

$\begin{array}{llllll}\text { Lack- } & 0.000008 & 0.000008 & 2.64 & 0.004 & 3\end{array}$ of-fit

$\begin{array}{llllll}\text { Pure } & 0.00001 & 0.00001 & - & - & 4\end{array}$

error

$\begin{array}{lllllll}\mathrm{R}^{2}= & \text { Model } & 0.000764 & 0.000764 & 20.66 & 0.011 & 5\end{array}$ $93.72 \quad(3 \mathrm{e})$

$\begin{array}{lllllll}\text { Adj } \mathrm{R}^{2}= & \mathrm{A}_{2} & 0.000243 & 0.000243 & 31.07 & 0.012 & 1\end{array}$

82.09

Pred $R^{2}=\quad \begin{array}{llllll}\mathrm{B}_{2} & 0.000557 & 0.000557 & 101.81 & 0.0368 & 1\end{array}$

79.21

$\begin{array}{cccccc}\mathrm{A}_{2}{ }^{2} & 0.00002 & 0.00002 & 7.63 & 0.047 & 1 \\ \mathrm{~B}_{2}{ }^{2} & 0.00001 & 0.00001 & 7.77 & 0.027 & 1 \\ \mathrm{~A}_{2}{ }^{*} \mathrm{~B}_{2} & 0.00007 & 0.00007 & 9.7 & 0.036 & 1 \\ \begin{array}{c}\text { Lack- } \\ \text { of-fit }\end{array} & 0.000052 & 0.000052 & 25.9 & 0 & 3 \\ \begin{array}{c}\text { Pure } \\ \text { error }\end{array} & 0.00002 & 0.00002 & - & - & 4 \\ \begin{array}{c}\text { Model } \\ \text { Mod }\end{array} & 0.009191 & 0.000383 & 42.83 & 0.001 & 5\end{array}$

$\begin{array}{ccc}\text { tfdC } & \mathrm{R}^{2}= & \text { Mode } \\ & 83.72 & (3 f)\end{array}$

$\operatorname{Adj} R^{2}=$

73.5

Pred

$\mathrm{R}^{2}=69.6$

pelA

$\begin{array}{llllll}\mathrm{A}_{2} & 0.000768 & 0.000768 & 6.43 & 0.0027 & 1\end{array}$

$\begin{array}{llllll}\mathrm{B}_{2} & 0.000301 & 0.000301 & 3.51 & 0.0054 & 1\end{array}$

$\begin{array}{llllll}\mathrm{A}_{2}{ }^{2} & 0.00021 & 0.00021 & 9.78 & 0.0048 & 1\end{array}$

$\begin{array}{llllll}\mathrm{B}_{2}{ }^{2} & 0.000742 & 0.000742 & 5.34 & 0.0023 & 1\end{array}$

$\begin{array}{llllll}\mathrm{A}_{2} * \mathrm{~B}_{2} & 0.000491 & 0.000491 & 1.09 & 0.00553 & 1\end{array}$

$\begin{array}{llllll}\text { Lack- } & 0.006268 & 0.000893 & 129.38 & 0.001 & 3\end{array}$

of-fit

$\begin{array}{lllllllll}\text { Pure } & 0.001105 & 0.000276 & - & - & 4\end{array}$

$\begin{array}{llllll}\text { error } & & & & & \\ \text { Model } & 0.000076 & 0.000076 & 32.71 & 0.003 & 5\end{array}$ $\begin{array}{cc}\mathrm{R}^{2}= & \text { Model } \\ 95.72 & (3 \mathrm{~g})\end{array}$

$\begin{array}{lllllll}\text { Adj } \mathrm{R}^{2}= & \mathrm{A}_{2} & 0.000044 & 0.000044 & 81.63 & 0.002 & 1\end{array}$

92.5

Pred

$\begin{array}{llllll}\mathrm{B}_{2} & 0000032 & 0.000032 & 94.78 & 0.000 & 1\end{array}$ 


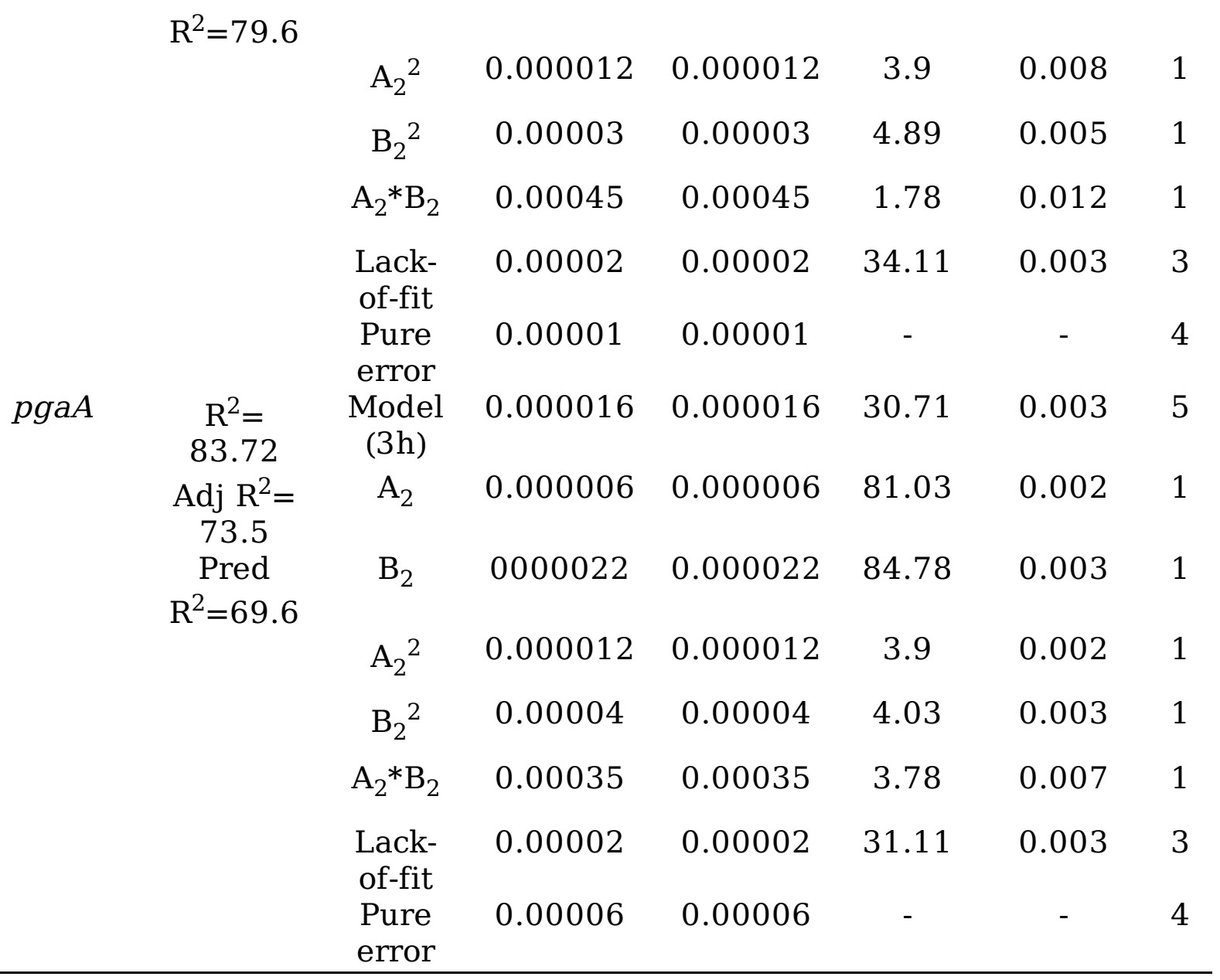

DF: degrees of freedom; $\mathrm{R}^{2}$ : determination coefficient; Adj $\mathrm{R}^{2}$ : adjusted R-squared; Pred $\mathrm{R}^{2}$ : predicted R-squared;

Table:3 Comparison of 2-4-D catabolic pathway genes (tfdc) of Pseudomonas.simiae EGD-AQ6 with homologous proteins of four Pseudomonas species reported for 2-4-D degradation ability. Analysed by GOLD database and NCBI nBLAST

\section{Supplementary tables}




\section{P.simiae WCS417 P.simiae PICF7 P.simiae K- P.simiae PCL hf-19 175}

\begin{tabular}{|c|c|c|c|c|}
\hline $\begin{array}{l}\text { tfdA/arhd ( 2-4-D } \\
\text { dioxygenase) }\end{array}$ & $99.3 \%$ & $99.3 \%$ & $98.2 \%$ & $96.7 \%$ \\
\hline$t f d B$ (2-4-D hydroxylase) & $94.2 \%$ & $91.2 \%$ & $94.5 \%$ & $95.1 \%$ \\
\hline $\begin{array}{l}\text { tfdC(chloro-catechol 1,2 } \\
\text { dioxygenase) }\end{array}$ & $99.8 \%$ & $97.2 \%$ & $98.1 \%$ & $98.7 \%$ \\
\hline $\begin{array}{l}t f d D \text { (chloro-muconate } \\
\text { cycloisomerase) }\end{array}$ & $99.1 \%$ & $98.2 \%$ & $96.8 \%$ & $96.2 \%$ \\
\hline$t f d E$ (di-enelactonehydrolase) & $99.2 \%$ & $93.9 \%$ & $97.3 \%$ & $98.1 \%$ \\
\hline $\begin{array}{l}t f d F(\text { maleylacetase } \\
\text { reductase) }\end{array}$ & $99.1 \%$ & $95.6 \%$ & $96.9 \%$ & $94.8 \%$ \\
\hline $\begin{array}{l}c b n R \text { (LysR family } \\
\text { transcriptional regulator in } \\
\text { chloroaromatic degradation) }\end{array}$ & $99.7 \%$ & $96.3 \%$ & $98.1 \%$ & $97.4 \%$ \\
\hline
\end{tabular}

\section{Figures}
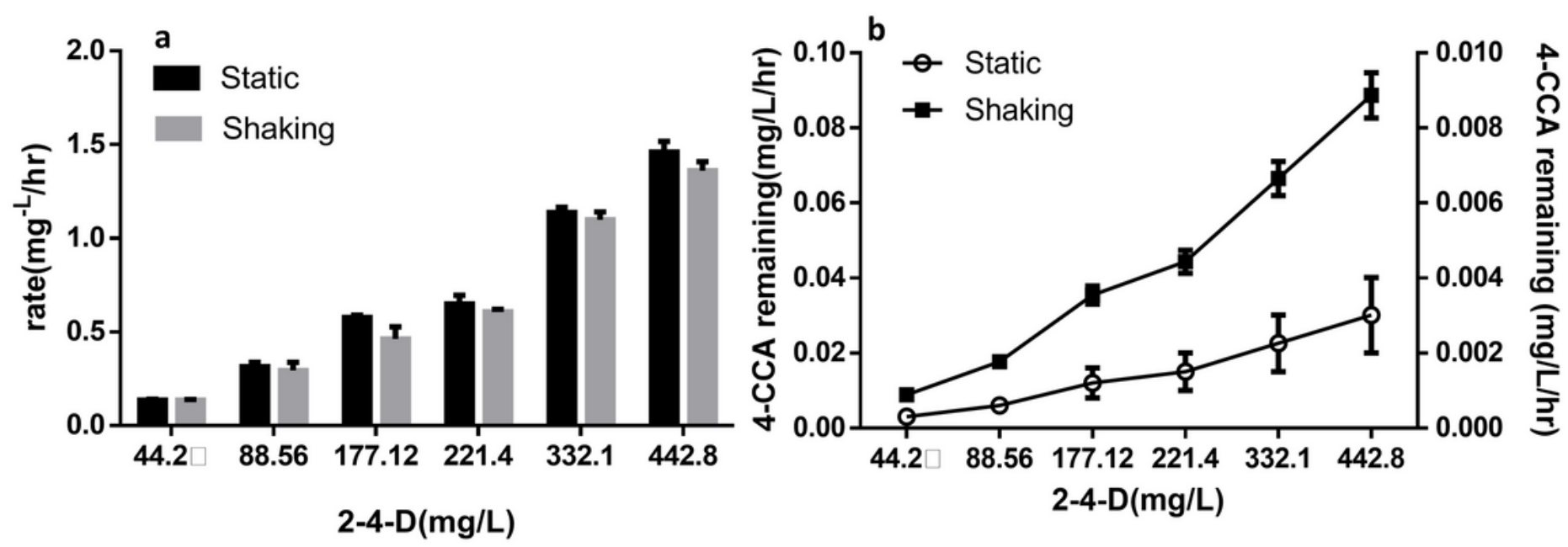

Figure 1

Biodegradation studies of Pseudomonas simiae EGD-AQ6. (a) Degradation rates of 2-4dichlorophenxyacetic acid (2-4-D) under static and shaking conditions. (b) Differential accumulation rates of intermediate 4-chlorocatechol (4-CCA) by Pseudomonas simiae EGD-AQ6 when 2-4-D was used 
as sole carbon source under static and shaking conditions. The values represents the mean \pm SD (error bars) of three replicates for at least two independent experiments at $p<0.05$.

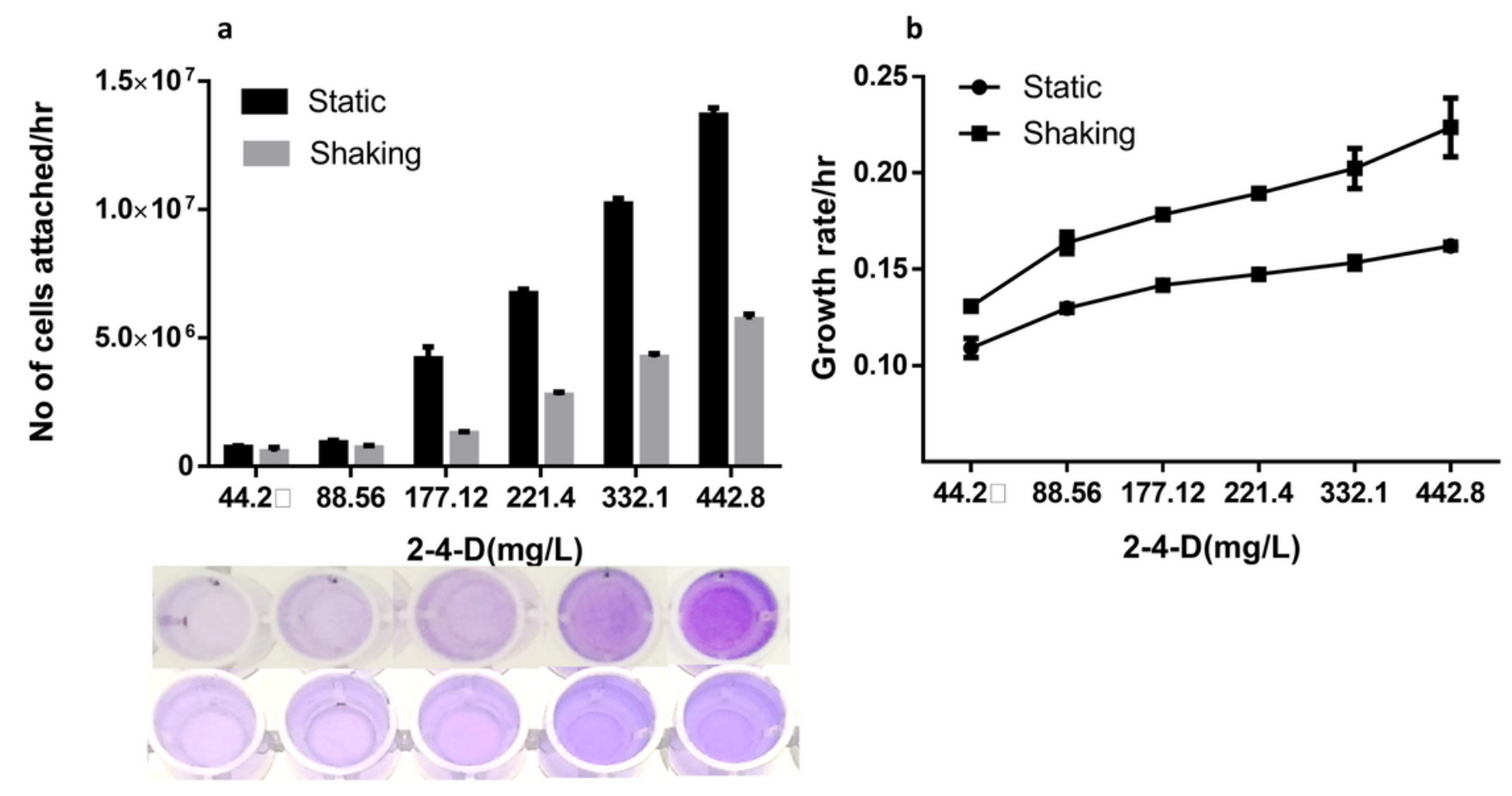

Figure 2

Graphs showing the (a) Rate of cell attachment (biofilm formation), (d) planktonic cells growth rates by Pseudomonas simiae EGD-AQ6 when 2-4-D was used as sole carbon source under static and shaking conditions. The values represents the mean \pm SD (error bars) of three replicates for at least two independent experiments at $p<0.05$. 
Static
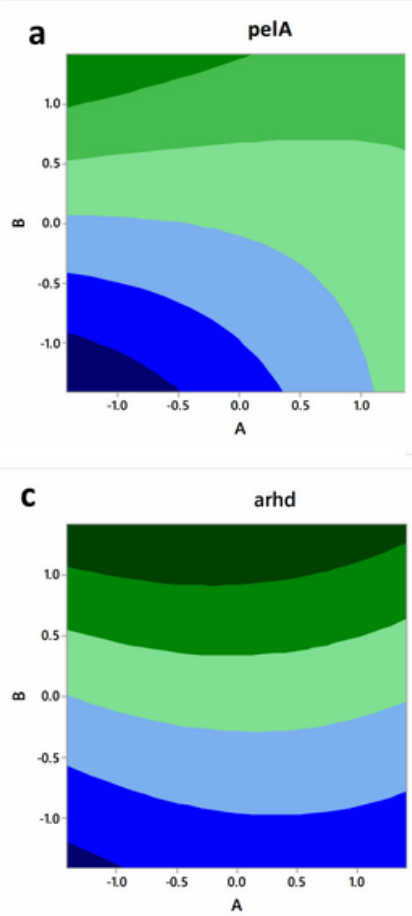
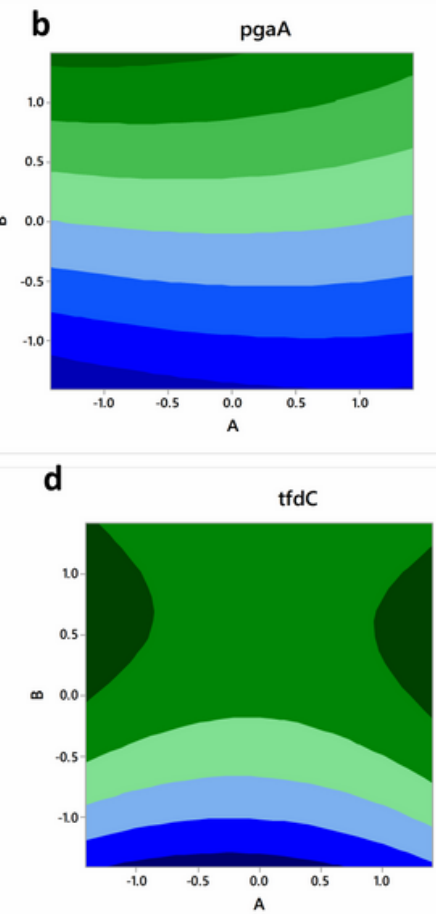

Shaking
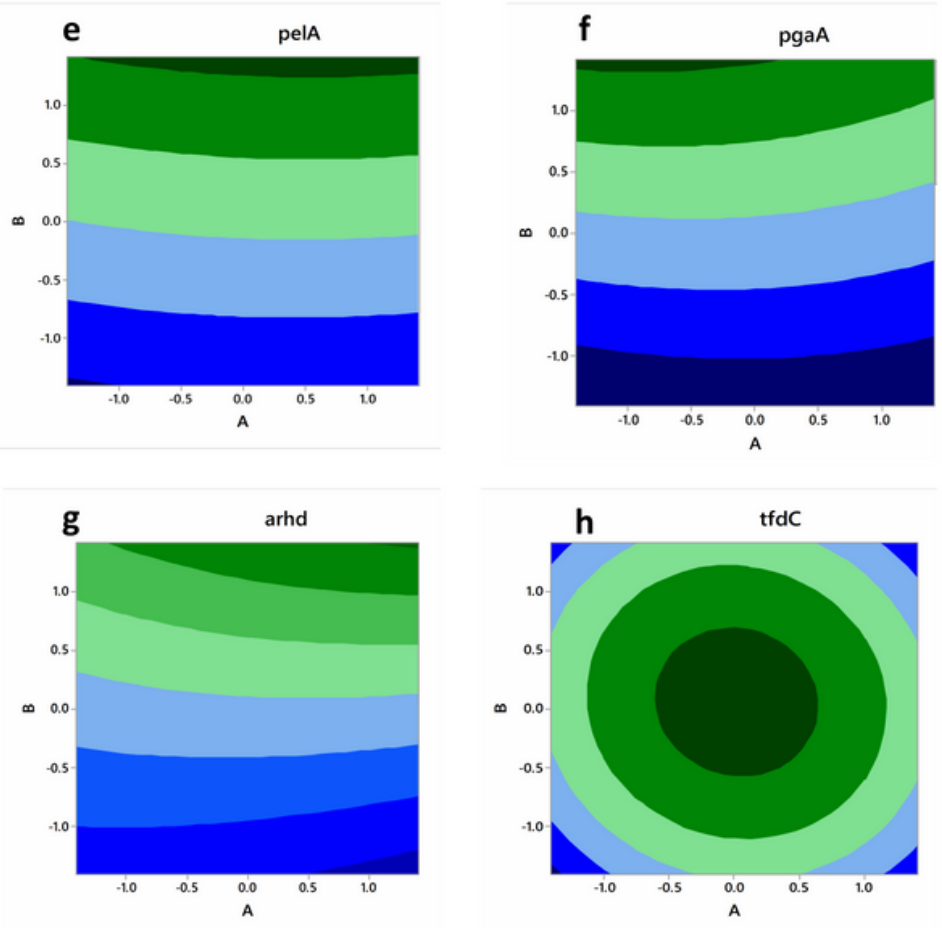

\section{Figure 3}

Contour plots showing the relative gene expression rates in biofilm and planktonic adapted phenotypes of Pseudomonas simiae EGD-AQ6 through response surface analysis. The factors A and B are 2-4-D degradation and 4-CCA accumulation rates. Relative gene expression representing mean fold change (log2) in differentially expressed mRNAs of Pseudomonas simiae EGD-AQ6 cells grown in presence of 24-D as determined by qRT-PCR. The fold change was depicted under static $(a, b, c, d)$ and shaking $(e, f, g, h)$ conditions for the genes (a) and (e) pelA (pellicle formation protein A), (b) and (f) pgaA (biofilm adhesin protein $\mathrm{A}$ ), (c) and (g) arhd (aromatic ring hydroxylating dioxygenase), (d) and (h) tfdC (chloro-catechol 1, 2 dioxygenase). The ranges of values increases from blue to green regions.

\section{Supplementary Files}

This is a list of supplementary files associated with this preprint. Click to download.

- SupplementaryTables.docx 